\title{
Perspectives on university library automation and national development in Uganda
}

By

Mr. Robert S. Buwule

Kyambogo University, Uganda; University of Pretoria, South Africa

Ass. Prof. Shana R. Ponelis

University of Wisconsin-Milwaukee, USA; University of Pretoria, South Africa

\begin{abstract}
Academic libraries in universities store large volumes of research that can be used for development purposes to support teaching, learning, research, innovation, community outreach and partnerships. Library automation incorporates the adoption of integrated library systems (ILS). Effective adoption of an ILS enables broad-based access to global and local knowledge sources to solve local, regional and national development challenges. Using a sequential mixed methods approach in a case study of a Ugandan public university, Kyambogo University, this study investigated the perceptions of librarians, information workers and other university stakeholders with respect to library automation and the contribution thereof to national development. The results confirmed that the ILS improved library operations and plays an important role in supporting national development. This study also highlights the continued challenges of adopting an ILS in developing countries such as Uganda, which, if addressed, could further improve information service delivery for a nation's socio-economic transformation.
\end{abstract}

\section{Keywords}

Academic library, university library, library automation, integrated library systems, technology adoption, access to information, national development, Uganda, Kyambogo University

\section{Introduction}

Academic libraries in universities store large volumes of research conducted at universities and other research institutions that can be used for development support teaching, learning, research, innovation, community outreach and partnerships (Bossaller and Atiso, 2015: 26). As such public - and private-academic libraries can play a central role in the collection and dissemination of both international and local content by providing access not only to students, faculty and researchers but also to the broader community and society.

Information and communication technologies (ICTs) are central in facilitating the effective storage, communication and dissemination of information. The World Summit on the Information Society (WSIS) declared that, "local authorities should play a major role in the provision of ICT services for the benefit of their populations" (WSIS, 2003). Fostering digital opportunities strengthens capacities for scientific research, information sharing, cultural creations and exchanges of knowledge (UNESCO, 2005). The International Federation of Library Associations and Institutions (IFLA, 2016) further believes that increasing access to information and knowledge across society with the help of available ICTs greatly supports 
sustainable development and contributes to improving people's lives. ICTs hold the potential to bridge socio-economic divides (Bossaller and Atiso, 2015: 27) and those in positions of authority have a responsibility to do so.

Library automation is the direct application of ICT to library functions such as acquisition, circulation, cataloguing and serials control (Amekuedee, 2005). Libraries automate their library services using integrated library systems (ILS) to improve efficiency and enhance access to library resources (Webber and Peters, 2010). The effective adoption of ICTs such as an ILS in academic libraries will "accelerate the level of knowledge acquisition and consequently improve national development" (Ani et al., 2005: 706).

Librarians and information workers were among the first to realise the importance of internet in the provision of information services to the public (De Saulles, 2007: 5). Librarians therefore partly fuelled the expansion in the quantity and communicability of information by adopting ICTs such as the ILSs and the internet in their libraries. The libraries' ability to make information available electronically directly facilitates interaction with information seekers in a more cost-effective manner (Amekuedee, 2005: 442). Individuals thus play an important role in ICT adoption and is reflected in virtually all technology adoption models, such as the perceived usefulness and perceived ease of use in Davis et al.'s (1989) Technology Acceptance Model (TAM) and in Rogers' Diffusion of Innovations (DoI) theory.

The purpose of this article is to determine the perceptions of the librarians and information workers involved in library automation and other stakeholders in Uganda with respect to library automation and the contribution thereof to national development. This paper is structured as follows: after a discussion of the role of universities in Africa and Uganda, a brief history of library automation is presented, Thereafter the methodology of the study, the results and a discussion follows. We conclude the paper with the key perspectives on the role of library automation on national development.

\section{The role of universities in Africa and Uganda}

The former United Nations Secretary-General, Kofi Annan, stated that, "The university must become a primary tool for Africa's development in the $21^{\text {st }}$ century" (Annan, 2005). According to Sutz (2005), "To increase their contribution to development through the production and distribution of knowledge, universities in developing countries need to transform themselves into developmental universities." Among others, such developmental universities must clarify, analyse and solve local, regional and national problems in partnership with government, industry, community and other research organizations and make resulting developmental knowledge available and accessible to the broader society regardless of socio-economic status (Fredua-Kwarteng, 2015; 2016).

The African Union (AU) agreed on a set of goals that all African countries are expected to achieve by 2063 (African Union Commission, 2015: 5). Rooted in pan-Africanism, Agenda 2063 provides a robust framework for addressing past injustices and the necessary infrastructure that supports accelerated integration and growth, technological transformation and development through African integration. In an effort to develop the capacity of Africa's citizens to be effective change agent for the continent's sustainable development as envisioned by the AU and 
its Agenda 2063, the African Union Commission has developed an Africa comprehensive tenyear continental education strategy. On January 31, 2016 heads of state attending the $26^{\text {th }}$ African Union Summit in Addis Ababa approved the Continental Education Strategy for Africa 2016-2025 (CESA 2016-2025). The objectives of CESA 2016-2025 include building, rehabilitating and supporting education infrastructure and revitalising and expanding tertiary education, research and innovation, particularly at a postgraduate level, to address continental challenges and promote global competitiveness.

Uganda is an East African landlocked country with a geographical area measuring 241,038 square miles with a population of 37 million people (BBC, 2016) that gained independence in 1962. Although Uganda is a multi-lingual country with more than 40 different languages, English was inherited from the colonial period as the language of government and education. Uganda, by sub-Saharan African standards, is one of the leading countries with a vibrant media sector with nearly 200 private radio stations, dozens of television stations and print outlets. By 2011, Uganda had 4.2 million internet users (BBC, 2016).

There are seven public universities licensed by the Uganda National Council of Higher Education. The majority of public and private universities are located in Central Uganda. Public universities have been established in other regions in recent years, the most recent being Lira University (2012) and Muni University (2014) in the Northern region, and Soroti University (2015) in the Eastern region. Although some universities are entirely new, several universities were formed by upgrading and/or merging tertiary and technical colleges; for example, Bishop Tucker Theological College (1913) became the Uganda Christian University in 1997 (chartered in 2004), and Kyambogo University (established in 2003) by merging the Uganda PolytechnicKyambogo (UPK), the Institute of Teacher Education-Kyambogo (ITEK) and the Uganda National Institute of Special Education (UNISE).

The Cabinet of the Republic of Uganda (2013: iii) approved a national vision for "a transformed Ugandan society from a peasant to a modern and prosperous country within thirty years." The Republic of Uganda (2013 :51) therefore plans to facilitate and nurture human resources and skills development to support national development. To achieve this, emphasis will be put on research and development, acquisition of modern scientific knowledge and technology, and building of knowledge networks. This will further be supplemented by building partnerships with local and international institutions. All this cannot be achieved without the dissemination of scientific information and knowledge through academic libraries that are automated and networked by means of an ILS.

\section{Brief history of library automation}

Library automation initiatives are first reported in the United States of America in the 1930s and later in Western Europe but took major strides in 1960s when the Library of Congress designed the Machine Readable Catalogue (MARC) format for communicating library bibliographic data on magnetic tape (Saffady, 1989: 273; Borgman, 1997: 21). Thereafter libraries started using key punched cards in combination with sorters, collators, and other unit record equipment in replacement of manual record keeping practices (Saffady, 1989: 270). In the 1970s more libraries started automating by sharing computer infrastructure which was very expensive at the time. This was the period that saw the writing of single-purpose software of cataloguing, 
circulation, serials control and other library functions. By this time other countries had developed their own MARC format and IFLA convened an international meeting to develop the Universal MARC (UNIMARC) standard.

It was in the late 1970s and the 1980s that saw the transition from in-house built library systems to integrated library systems. Through their local area networks and dial-up modems, libraries set up online catalogues while others shared bibliographic data and set up union catalogues (Borgman, 1997: 223). It was also around this time that this technology started to be adopted in some leading African libraries most especially in South Africa. In sub-Saharan Africa the library automation campaign was spearheaded by the United Nations Education Scientific and Cultural Organisation (UNESCO). Computerised Documentation Services/Integrated Set of Information System (CDS/ISIS) was developed and distributed to many academic and public libraries in this region to automate their bibliographic information (Mutula, 2012: 295). CDS/ISIS was not only used in Africa but was widely used by libraries, information and documentation centres throughout the world where no predefined library automation structures or standards were available (De Smet, 2009: 63).

Not very different from the African experience, many Asian and Central and Eastern Europe libraries entered the 1990s with minimal library automation with mostly bibliographic databases and applications on standalone computers (Borgman, 1997: 223). This is confirmed by Husain and Ansari (2007: 146) who report that library automation gained some momentum in India in the 1990s driven mainly by the sharply dwindling prices of computer hardware, availability of ILSs and the increased enthusiasm of library professionals for embracing technology. Haider (1998) also reports of the same scenario in Pakistan. The emergence of internet in the 1990s added a new flavour to library automation as both library workers and users started to remotely access the library catalogue (Mutula, 2012: 294). The twenty-first century came with free and open source software (FOSS) as an intervention to the digital divide that had by this time been created between the automated libraries in the developed world and the traditional and manual libraries in the developing world like Uganda. There were a number of FOSS that were developed around this time like Koha and Evergreen (Mutula, 2012: 295). UNESCO also upgraded the CDS/ISIS which was DOS-based to WINISIS for MS Windows and later to ABDC for a web-based environment (De Smet, 2009: 63).

Today significant advancements in sophisticated ICTs have triggered dynamic changes in software, hardware, networks and mobile technology which are constantly increasing the capacities of ILSs (Rosa and Storey, 2016). Cloud computing is creating highly scalable platforms that facilitate quick access to hardware and software over the internet, in addition to easy management and access by non-expert users (Romero, 2012: 110). Coupled with the mass penetration of mobile smartphones and tablets, broad-based adoption and access is increasingly possible.

\section{Methodology}

A single case, Kyambogo University (KyU), was selected and studied in-depth using a sequential exploratory mixed methods design (shown in Figure 1) to elicit the perspectives from the target population, KyU staff and students, on library automation and the role the ILS plays in supporting national development. Although a single case limits generalizability of the study, the 
access and familiarity of the lead author ensured the case was information rich with respect to the topics under investigation (Patton, 2002).

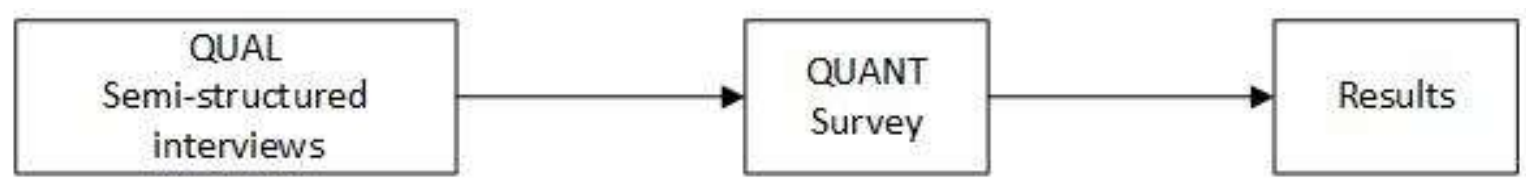

Figure 1. Research design

In the qualitative strand, semi-structured interviews were conducted in English with 26 purposively selected participants, representing $28.6 \%$ of the target population. Semi-structured interviews allowed the researchers to ask standard questions supplemented by individually tailored questions to probe research subjects' reasoning or to get more clarification (Leedy and Ormrod 2010: 188). In the subsequent quantitative strand a questionnaire, also in English, based on results from the first strand was used to survey the entire target population for which the overall response rate was $91.2 \%$. Table 1 provides the detail on the target population and sampling strategies for each strand.

Table 1. Target population and sample response rates

\begin{tabular}{|c|c|c|c|c|c|c|}
\hline \multirow{2}{*}{\multicolumn{2}{|c|}{ KyU Section/Unit }} & \multirow{2}{*}{$\begin{array}{l}\text { Total } \\
\text { population }\end{array}$} & \multicolumn{2}{|c|}{ Interviews } & \multicolumn{2}{|l|}{ Survey } \\
\hline & & & (n) & $(\%)$ & (n) & $(\%)$ \\
\hline \multicolumn{2}{|c|}{ KyU top management } & 8 & 1 & 12.5 & 6 & 75 \\
\hline \multirow[t]{3}{*}{ KyULS } & Management team & 9 & 3 & 33.3 & 9 & 100 \\
\hline & ICT Unit & 6 & 5 & 83.3 & 5 & 83.3 \\
\hline & General library staff & 32 & 12 & 37.5 & 31 & 96.9 \\
\hline \multicolumn{2}{|c|}{ KyU Library Committee members } & 13 & 2 & 15.4 & 12 & 92.3 \\
\hline \multicolumn{2}{|c|}{ KyU ICT Unit (e-Kampus) } & 5 & 1 & 20 & 4 & 80 \\
\hline \multicolumn{2}{|c|}{ The Students Guild } & 18 & 2 & 11.1 & 16 & 88.9 \\
\hline \multicolumn{2}{|l|}{ Total } & 91 & 26 & 28.6 & 83 & 91.2 \\
\hline
\end{tabular}

KyU: Kyambogo University

KyULS: Kyambogo University Library Service

Document review was used to inform and support the development of data collection instruments as well as the analysis and interpretation thereof. Documents included published and unpublished reports from $\mathrm{KyU}$, administrative documents, newspapers, journal articles and books in print and electronic (Nieuwenhuis, 2016: 88). The document data gathering technique helped in reconstructing events, critical incidences and their social relationships.

Sequential mixed data analysis was used to analyse the data collected from the interviews (Teddlie and Tashakkori, 2009). All quantitative data was analysed using SPSS statistical software to generate descriptive statistics.

\section{Background on the case}

Kyambogo University (KyU) is one of the seven public universities of Uganda (Uganda National Council of Higher Education, 2016). As mentioned above KyU was established in 2003 by 
amalgamating three existing institutions. Following the merger of the three institutions, the three institutional libraries were merged to form the Kyambogo University Library Service (KyULS) (Kyambogo University, 2016). There is hardly anything reported about the automation initiatives before the merger. Mutula (2000) briefly reports that UPK library was accessing the African Virtual University Digital Library, which was searchable via internet. Attempts at automating the Kyambogo University library catalogue post-merger with an in-house built solution were initiated by the staff members based on the local needs of the three branch libraries in 2009 using Microsoft Access. The respective databases were never integrated as each branch used a standalone computer and there was no network linking the branches of KyULS.

In 2011 KyULS started entertaining the idea of adopting an ILS. This idea given further credibility by the Consortium of Uganda University Libraries (CUUL) that organised training in 2012 for its member institutions, which included KyU, in Koha. Koha is an open source, predominantly web-based ILS and is widely being adopted by academic libraries with low cost budgets around the world. CUUL has actively encouraged academic libraries across East Africa to adopt Koha and has conducted several training sessions on Koha since 2011 (Adoma and Ponelis, 2015). The KyULS staff member who attended CUUL's Koha training was supposed to train other staff members at $\mathrm{KyU}$ and a one-week Koha training session was organised at $\mathrm{KyU}$ for a few key staff in April 2013. Koha software was then installed on the university server and customised beginning in June 2013. Another Koha orientation for a selected number of library staff was carried out in August 2013 and thereafter Koha was launched in KyU.

Study programs and student intakes are increasing yearly. KyU's current enrolment is over 20,000 students on campus and over 60,000 students from 63 affiliated institutions, mainly primary and secondary teacher training colleges. KyU's physical library space is not in any way able to house the 80,000 students, staff members and external users and the only alternative is to access the library online. The adoption of Koha opened up KyU to a number benefits of ILSs enumerated by Ayankola and Ajala (2012) including flexibility, speed, ease of updating and manipulation of bibliographic data, remote access to an item by multiple users simultaneously. However, like at the University of Malawi's academic libraries, there is a low level of computer technology replacement (Mapulanga, 2013). A few computers and ICT equipment donated to support library automation initiatives in KyULS are almost obsolete.

\section{Study results}

\section{Contribution of library automation to library operations}

The majority of respondents indicated that library automation contributes to academic library operations (79 respondents, 95\%). Respondents were asked to identify scenarios of where and how automation of academic libraries and information centres improves library information services (Table 2). 
Table 2. How library automation supports library operations

\begin{tabular}{|l|r|r|r|}
\hline \multirow{2}{*}{ Theme } & \multicolumn{3}{|l|}{ Frequency } \\
\cline { 2 - 4 } & $(\boldsymbol{n})$ & $\begin{array}{l}(\mathbf{\%}, \boldsymbol{n = 8 3} \\
\text { respondents })\end{array}$ & $\begin{array}{l}(\mathbf{\%}, \boldsymbol{n = 5 9 2} \\
\text { responses })\end{array}$ \\
\hline Tracks library records & 78 & 94 & 15.9 \\
\hline Saves time & 74 & 89.2 & 15.1 \\
\hline Increases productivity & 73 & 88 & 14.9 \\
\hline Eases work & 70 & 84.3 & 14.2 \\
\hline Increases efficiency & 68 & 81.9 & 13.8 \\
\hline Allows interoperability & 64 & 77.1 & 13 \\
\hline Saves costs & 59 & 71.1 & 12 \\
\hline Ensures accuracy & 59 & 71.1 & 12 \\
\hline Increases library's influence & 47 & 56.6 & 9.6 \\
\hline
\end{tabular}

\section{Contribution of library automation to national development}

In the first strand, interviewees were asked to assess whether library automation contributes to national development, directly or indirectly, and the majority (88\%) stated that it does. Those interviewees who felt that library automation contributes to national development were asked to elaborate on reasons for their affirmation. A list of possible impacts of automation in university libraries was provided from which interviewees selected the following as the top contributions:

- speeds up service delivery;

- improves access for those with physical disabilities;

- promotes the library as a centre of excellence;

- increases the visibility of the nations' local content; and

- aligns the library with the national vision.

Survey respondents in the second strand were provided with a list of the 8 Millennium Development Goals (MDGs) ${ }^{1}$ and asked about the contribution of library automation to the achievement of the MDGs. (At the time of data collection, the United Nations had not yet launched the Sustainable Development Goals or SDGs.) According to the results of the study, $83.1 \%$ of the respondents affirmed that library automation directly or indirectly contributed to the achievement of the MDGs. These respondents further elaborated on the different ways library automation has contributed to the achievement of the MDGs. As shown in Table 3, the primary contribution of library automation to MDGs is seen to be enabling faster and easier access to large stores of information with support for research and innovation a secondary contribution.

\footnotetext{
${ }^{1}$ See the United Nations Development Programme's overview and achievement of the MDGs at http://www.undp.org/content/undp/en/home/sdgoverview/mdg_goals.html.
} 
Table 3. Library automation and impact on the Millennium Development Goals

\begin{tabular}{|l|l|r|}
\hline \multirow{2}{*}{ Positive impact } & \multicolumn{2}{|l|}{ Frequency } \\
\cline { 2 - 3 } & $(\boldsymbol{n})$ & $\begin{array}{l}(\boldsymbol{\%}, \boldsymbol{n = 8 3} \\
\text { respondents })\end{array}$ \\
\hline Provides faster and easier access to information & 65 & 78.3 \\
\hline Enables mass storage of information & 54 & 65.1 \\
\hline Facilitates research for development & 54 & 65.1 \\
\hline Supports scientific innovation & 31 & 37.3 \\
\hline Provides a competitive advantage for KyULS & 17 & 20.5 \\
\hline
\end{tabular}

KyULS: Kyambogo University Library Service

Survey respondents in the second strand were also asked whether library automation facilitates collaboration and networking among library workers and users for purposes of development both nationally and internationally. As shown in Table 4, the majority of respondents (63.9\%) believe that library automation creates a firm foundation of international cooperation, networking and collaboration. The respondents who believed that library automation enhances collaboration and networking reasoned that library automation allows library staff members and users to collaborate with developmental experts, researchers, innovators and (potential) investors online and generally share experiences of accessing information online. These respondents were requested to rate their prior experience of collaboration through library automation. All 53 respondents rated their experience as either very good, good and fair with $43.4 \%$ assessing their experience as very good (Table 5).

Table 4. Library automation facilitates collaboration and networking for national development

\begin{tabular}{|l|r|r|}
\hline \multirow{2}{*}{ Answer } & \multicolumn{2}{|l|}{ Frequency } \\
\cline { 2 - 4 } & $(\boldsymbol{n})$ & \multicolumn{1}{|c|}{$(\boldsymbol{\%})$} \\
\hline Yes & 53 & 63.9 \\
\hline No / No opinion & 30 & 36.1 \\
\hline Total & $\mathbf{8 3}$ & $\mathbf{1 0 0}$ \\
\hline
\end{tabular}

Table 5. Experience of external collaboration as a result of library automation

\begin{tabular}{|l|r|r|}
\hline \multirow{2}{*}{ Level of experience } & \multicolumn{2}{|l|}{ Frequency } \\
\cline { 2 - 3 }$(\boldsymbol{n})$ & 23 & \multicolumn{1}{l|}{$(\boldsymbol{\%})$} \\
\hline Very good & 25 & 43.4 \\
\hline Good & 5 & 9.4 \\
\hline Fair & - & - \\
\hline Poor & - & - \\
\hline Very poor & $\mathbf{5 3}$ & $\mathbf{1 0 0}$ \\
\hline Total & \multicolumn{2}{|}{} \\
\hline
\end{tabular}




\section{Challenges to adopting integrated library systems in developing countries}

Challenges confounding successful adoption and use of the ILS were mentioned by several interviewees. Survey respondents were thus asked to indicate challenges encountered in library automation. Table 6 lists the barriers to library automation at KyULS.

Table 6. Barriers to library automation

\begin{tabular}{|l|r|r|}
\hline \multirow{2}{*}{ Barrier } & \multicolumn{3}{|l|}{ Frequency } & \\
\cline { 2 - 3 } & $(\boldsymbol{n})$ & \multicolumn{1}{l|}{$\begin{array}{l}\mathbf{\%}, \boldsymbol{n = 8 3} \\
\text { respondents })\end{array}$} \\
\hline Internet instability & 70 & 84.3 \\
\hline Procurement bureaucracies & 70 & 84.3 \\
\hline Inadequate top management support & 69 & 83.1 \\
\hline Lack of infrastructure & 65 & 78.3 \\
\hline Shortage of funding & 68 & 81.9 \\
\hline Inadequate staff skills & 52 & 62.7 \\
\hline Ever-changing technology & 33 & 39.8 \\
\hline Technophobia* & 5 & 6.0 \\
\hline Lack of initiative* & 4 & 4.8 \\
\hline Initial stage not well managed* & 1 & 1.2 \\
\hline Lack of champions* & 1 & 1.2 \\
\hline
\end{tabular}

* As specified under 'Other' option in questionnaire responses

\section{Discussion}

The results show that library staff at KyU reported that the ILS improved library operations, including the ability to catalogue their holdings for users' benefit by improving information service provision. The relatively recent automation of KyULS gives the staff a good basis of comparison in terms of improvements to library operations before and after the ILS implementation. The results also confirm the benefits of library automation and implementation of an ILS that has been widely reported in the literature; for example, Walsh (2012: 43) reports how libraries have migrated from sending paper messages to sending them by email or SMS using their ILSs which saves time, postage costs, reduces delivery staff and space. Respondents in this study demonstrated support of the ILS as well as its role in supporting national development, particularly by making knowledge, both global and local, widely accessible and supporting research and innovation. Thanks to ILSs, countries and their citizens can expect their public academic libraries to be able to provide seamless connections to information sources, facilitate remote access to local and international databases to meet their various information needs, support research and innovation and, ultimately, contribute to their national development agendas. Furthermore, the ILS' facilitation of collaboration and sharing across institutional boundaries is also seen as contributing to national development efforts.

When library users find it easy to access information through the ILS, the nation's education sector is automatically supported as thousands of students, investors, policy makers and all information seekers remotely access all the information they need to execute their duties for the nation's benefit. Healy (2008: 185) posits that university libraries and most especially public ones are uniquely positioned to increase access to information since they provide services such 
as internet access to members of the community. Providing access to internet coupled with a functional information searching and retrieval tool, the ILS, is a significant step toward providing access to information for national development.

Universities and institutions of higher learning have long been the primary producers of original research that has lead to many world changing innovations (De Saulles, 2012: 41). Traditionally universities have been disseminating this research information through peer-reviewed journals however the trend is shifting to institutional repositories which are linked to ILS which ease access to this research and innovation information in universities. Conversely, the lack of timely access to textbooks and other relevant information materials leads to students losing interest in learning and thus they no longer invest time in reading. Therefore this has having a negative impact on their innovativeness, literacy and general knowledge (UNCST, 2012).

As reflected in the results above library automation enhances collaboration and networking between other academic institutions which can be used to develop the career path of information and knowledge seekers through peer learning support, mentorship and placement services. For example, according to Mutula (2012: 300), library automation offers access to a diversity of electronic resources from different providers and this digital scholarship encourages collaboration and networking in all aspects of the library users' learning experience. Library automation further contributes to knowledge dissemination since KyULS' Online Public Access Catalog (OPAC) enables worldwide access and thus increases the visibility of a nation's local content. Librarians at KyULS should explore creative ways that can increase the visibility of their academic libraries through working with different faculties, schools and colleges to promote the use of ILSs (Liu and Luo, 2011: 235).

As library users are inspired to read, learn, complete assignments, reflect and think, this impact can be felt even on the national level. Missingham and Moreno (2005: 32) allude to this fact that national development needs to involve all sectors of a nation. Players in national development have to put platforms like ILSs which allow all inclusive participation and resource sharing on local and international networks. Bossaller and Atiso (2015: 34) state that stable and sustained ILSs allow scientists in developing nations to share their work, create collaborative relationships, and create solutions for the most pressing issues in their countries. Academic libraries as leading agencies of disseminating knowledge, create an egalitarian platform for all (Eklow, 2012: 481). The results show that KyU staff see that library automation contributed to the achievement of the MDGs. With the introduction of the SDGs, libraries continue to have an essential role through providing access to information to the public to support development (Bradley, 2016: 118). The library further uses its ICTs to preserve and ensure ongoing access to developmental information for future generations.

Because ICT plays such a central and highly visible role in library automation it is easy to forget that library automation as an innovation encompasses more than just the hardware and ILS software. Successful adoption and adaptation of information systems such as an ILS requires the diffusion of supporting higher-context dependence innovations around techniques, procedures, education and training, funding policies and governance policies (Lor, 2014). The respondents' concerns with respect to the challenges of ILS implementation and use are similar to those widely reported in the literature on library automation in sub-Saharan Africa: a lack of 
infrastructure (reliable power supply, equipment, connectivity), skills base (LIS education and training), management support and supporting policies and procedures (operational, funding, procurement). Consider for example, the Ugandan government's plan to provide free solarpowered laptops to all Ugandan university students, which would reduce costs associated with buying printed textbooks, photocopying teaching materials, and improve access for persons with disabilities (Anguyo, 2014: 26). This plan, however, is questionable since there is no corresponding infrastructure to enable access to information through, for example, broadband connectivity. The biggest impediment is funding. While funding is necessary it is not sufficient. Given sufficient funds, any library can purchase ICTs but it takes considerable skill to implement an ILS because it changes the way people work, the processes of the library, and users' relationship with the library (Negash et al., 2012: 270).

Library automation may still not deliver on access to information to the relevant stakeholders without skills and leadership. According to Scheeder and Witt (2016: 83), IFLA proposes the first level of change agenda as reskilling, if library automation is to significantly influence the achievement of national and international development. Librarians must personally embrace the required skills that are needed to use ILS to offer services that can positively transform the society. Reskilling automatically calls for high levels of creativity and innovation among librarians. This may also entail LIS training institutions equipping students with up-to-date skills in the use of ILSs. In order to empower academic libraries to positively influence national development, leadership development should be considered. Mutula (2012:301) suggests that these common challenges can be overcome by partnering with consortia, and imparting continuous pedagogic training in library automation to academic library staff.

The lack of appreciation by policy-makers of the role libraries play in the development of Uganda reported by Okello-Obura and Kigongo-Bukenya (2011) is a critical issue. Libraries and university management should play a leading role in advocating for libraries and creating greater awareness of the central role that academic libraries play national development is vital, particularly given initiatives to transform higher education through the AU's Agenda 2063 and CESA 2016-2026 and the Ugandan government's Vision 2040. The recently released Omaswa Task Force Report (Nakkazi, 2016) recommends the formation of 'innovation universities' in Uganda to serve as engines of industrialisation and economic growth, requiring substantial restructuring of Uganda's nine public universities. Furthermore, the Minister for Higher Education, Science and Technology, Hon. Tickodri-Togboa, stated that higher education institutions must be transformed into "vehicles of industrialisation, employment-wealth creation, inclusive and sustainable development and socio-economic transformation in line with Uganda Vision 2040" (Nakkazi, 2016). Libraries and their institutional leadership need to ensure that they are adequately empowered and enabled to support a successful transformation.

Challenges that inhibit library adoption and ILS implementation and use are unlikely to be adequately addressed without a greater appreciation of the important role that libraries play. Given that inadequate top management support was seen as a major barrier, librarians should commence by advocating internally to canvas support for initiatives and also to increase awareness among policy-makers with respect to development. Libraries are also not mentioned in any of the SDGs, in spite of the Lyon Declaration on Access to Information and Development launched at the World Library and Information Congress in 2014 and the vital role libraries and other information centres can play in support of all 17 SDGs (IFLA, 2016). 


\section{Conclusion and implications}

Academic libraries are among the leading agencies supporting knowledge production and disseminating knowledge within a country. This study shows that academic librarians in research and tertiary institutions such as $\mathrm{KyU}$ can make a difference that will support national development through ensuring operational ILSs in their libraries that connect all citizens through library automation so that they can communicate and share knowledge with others locally, nationally, regionally and globally. Academic libraries should lobby their university management and policy-makers in national governments to support libraries and, in general, to implement ILSs. It will also be necessary to have an accompanying infrastructure with updated computers, connectivity, and LIS education and training. There can be no library automation without investment in the supporting infrastructure. Governments and development partners should fund academic libraries so they may improve information service delivery through their ILS to assist with socio-economic transformation. Ultimately, such funding for university libraries is vital for the achievement of Uganda's Vision 2040 and, more broadly, the AU's Agenda 2063.

\section{Declaration of Conflicting Interests}

The authors declared no potential conflicts of interest with respect to the research, authorship, and/or publication of this article.

\section{Funding}

The financial assistance of the Carnegie Corporation of New York (CCNY) that made this study possible is hereby acknowledged. Opinions expressed and conclusions arrived at, are those of the authors and are not to be attributed to the CCNY.

\section{References}

Adoma P and Ponelis SR (2015) Open source integrated library systems in academic libraries in Uganda: initial results. IFLA WLIC IT Section Satellite Meeting, Stellenbosch University, Stellenbosch, South Africa, 13-14 August 2015.

African Union Commission (2015) Agenda 2063: The Africa we Want Popular Ed. Addis Ababa: African Union Commission. Available at: http://www.un.org/en/africa/osaa/pdf/au/agenda2063.pdf (accessed 18 April 2017).

Amekuedee JO (2005) An evaluation of library automation in some Ghanaian university libraries. The Electronic Library 23(4): 442-452.

Anguyo I (2014) Is Government provision of Computers to Varsity Student Realistic? New Vision. 17 December, p. 26.

Annan, K (2005) Statement by H. E. Mr. Kofi Annan, Secretary-General of the United Nations. Opening statement presented at the Second Phase of the World Summit on the Information Society, Tunis, Tunisia, 16 November 2005. Available at: http://www.itu.int/net/wsis/tunis/statements/docs/io-un-opening/1.html (accessed 25 April 2017).

Ani OE, Esin JE and Edem N (2005) Adoption of information and communication technology (ICT) in academic libraries. The Electronic Library 23(6): 701-708.

Ayankola IA and Ajala SF (2012) The Challenges and Frustration of Software Adoption in Nigeria Libraries: A Survey of Some Selected Libraries. Philosophy and Practice (ejournal): 1-17.

BBC (2016) Uganda country profile. Web document. Available at: 
http://www.bbc.com/news/world-africa-14107906 (accessed 15 November 2016).

Borgman CL (1997) From Acting Locally to Thinking Globally: A Brief History of Library Automation. The Library Quarterly 67(3): 215-249.

Bossaller J and Atiso K (2015) Sharing science: The state of institutional repositories in Ghana. IFLA Journal, 4(1): 25-39.

Bradley F (2016) "A world with universal literacy": The role of libraries and access to information in the UN 2030 Agenda. International Federation of Library Associations and Institutions 42(2): 118-125.

Davis FD, Bagozzi RP and Warshaw PR (1989) User Acceptance of Computer Technology: A Comparison of Two Theoretical Models. Management Science 35(8): 983-1003.

De Saulles M (2007) Information Literacy among UK SMEs: an Information Policy Gap. Aslib Proceedings: New Information Perspectives 59(1): 68-97.

De Saulles M (2012) Information 2.0: New Models of Information Production, Distribution and Consumption. London: Facet Publishing.De Smet E (2009) ABCD: a new FOSS library automation solution based on ISIS. Information Development 25(1): 61-67.

Eklow S (2012) Re-Positioning the Library in the University: Aligning Library Acquisitions. In: The Standing Conference of Eastern, Central and Southern African Library Associations. Nairobi, Kenya.: Kenya Library Association.

Fredua-Kwarteng E (2015) The case for developmental universities. University World News, 30 October. Available at:

http://www.universityworldnews.com/article.php?story=20151028020047530 (accessed 18 April 2017).

Fredua-Kwarteng E (2016) Ethics and the developmental university, University World News, 23 September, Available at: http://www.universityworldnews.com/article.php?story=20160923113239206 (accessed 18 April 2017).

Haider SJ (1998) Library automation in Pakistan. International Information and Library Review, 30(1): 51-69.

Healy AM (2008) MedlinePlus Go Local: Connecting at-risk Populations with Health Care Services. In: Charbonneau DH (ed) Global Information Inequalities: Bridging the Information Gap. Oxford: Chandos Publishing, pp. 177-188.

Husain S and Ansari MA (2007) Library Automation Software Packages in India: A Study of the Cataloguing Modules of Alice for Windows, Libsys and Virtual. Annals of Library and Information Studies 54(September): 146-151.

International Federation of Library and Information Associations and Institutions (IFLA) (2016) Access and opportunity for all: How libraries contribute to the United Nations 2030 Agenda. The Hague, Netherlands: IFLA.Available at: http://www.ifla.org/files/assets/hq/topics/libraries-development/documents/access-andopportunity-for-all.pdf.

Kyambogo University (2016) History of the University. Available at: http://kyu.ac.ug/index.php/contact-us/logo/history.

Leedy PD and Ormrod JE (2010) Practical Research: Planning and Design. Ninth edition. Upper Saddle River, NJ: Merrill.

Liu Z and Luo L (2011) A Comparative Study of Digital Library Use: Factors, Perceived Influences, and Satisfaction. The Journal of Academic Librarianship 37(3): 230-236. Lor PJ (2014). Understanding innovation, policy transfer and policy borrowing: implications for 
LIS in Africa. In: $7^{\text {th }}$ Annual Public Lecture on African Librarianship in the $21^{\text {st }}$ Century, University of South Africa, Pretoria, 22 May 2014. Available at:

https://pjlor.files.wordpress.com/2014/06/understanding-innovation.pdf (accessed 18 April 2017).

Mapulanga P (2013) SWOT Analysis in the planning of information services and systems in university libraries: The case of the University of Malawi Strategic Plans. The Bottom Line 26(2): 70-84.

Missingham M and Moreno R (2005) Resource sharing in Australia: evaluation of national initiatives and recent developments. Interlending and Document Supply 33(1): 26-34.

Mutula SM (2000) IT Development in Eastern and Southern Africa: Implications for University Libraries. Library Hi-Tech 18(4): 320-334.

Mutula SM (2012) Library automation in sub Saharan Africa: case study of the University of Botswana Program. Electronic library and information systems 46(3): 292-307.

Nambogga J (2015) Embrace ICT, Migereko advises youth. New Vision, 25 February, p. 11.

Nakkazi E (2016) Sweeping university reforms to emphasise innovation. University World News, 3 June 2016, 416. Available at:

http://www.universityworldnews.com/article.php?story=20160603095608368 (accessed 18 April 2017).

Negash S, Anteneh S and Watson RT (2012) A PhD in information systems for emerging economies: The Addis Ababa University model. Information Technology for Development 18(3): 270-276.

Nieuwenhuis J (2016) Qualitative Research Designs and Data Gathering Techniques. In: Maree $\mathrm{K}$ et al. (eds) First Step in Research. Pretoria: Van Schaik Publishers, pp. 72-103.

Okello-Obura C and Kigongo-Bukenya IMN (2011) Library and information science education and training in Uganda: trends, challenges and the way forward. Education Research International 2011: 1-9.

Patton MQ (2002) Qualitative Evaluation and Research Methods. Third edition. Newbury Park, California: SAGE Publications.

Republic of Uganda. (2013). Uganda Vision 2040. Kampala: National Planning Authority. Available at: http://npa.ug/wp-content/themes/npatheme/documents/vision2040.pdf (accessed 18 April 2017).

Romero NL (2012) "Cloud computing" in library automation: benefits and drawbacks. The Bottom Line 25(3): 110-114. Available at: http://dx.doi.org/10.1108/08880451211276566.

Rosa K and Storey T (2016) American libraries in 2016: Creating their future by connecting, collaborating and building community. IFLA Journal, 42(2): 85-101.

Saffady W (1989) Library Automation: An Overview. Library Trends 37(3): 269-81.

Scheeder D and Witt S (2016) Libraries: A Call to Build the Action Agenda. IFLA Journal 42(2): 83-84.

Sutz J (2005) The role of universities in knowledge production. Himalayan Journal of Sciences 3(5): 53-56.

Teddlie C and Tashakkori A (2009) Foundation of mixed methods research: integrating quantitative and qualitative approaches in the social and behavioural sciences. Thousand Oaks, California: SAGE Publications.

Uganda National Council of Higher Education (2016) Public Universities. Available at: http://www.unche.or.ug/institutions/public-universities (accessed 18 April 2017).

UNCST (2012) Uganda National Council of Science and Technology: The quality of Science 
Education in Uganda, Kampala Uganda.

UNESCO (2005) Towards Knowledge Societies. Paris, France: UNESCO.

Walsh A (2012) Using Mobile Technology to Deliver Library Services: A Handbook. London: Facet Publishing.

Webber D and Peters A (2010) Integrated Library Systems: Planning Selecting and Implementing. Santa Barbara, California: Libraries Unlimited.

World Summit on the Information Society (WSIS) (2003) WSIS Declaration of Principles: Building the Information Society: A Global Challenge in the New Millennium (WSIS03/GENEVA/DOC/4-E), Geneva, 12 December 2003. Available at:

http://www.itu.int/net/wsis/docs/geneva/official/dop.html (accessed 18 April 2017). 